\title{
The Decline in Household Saving and the Wealth Effect
}

\author{
F. Thomas Juster, Joseph P. Lupton, James P. Smith, and Frank Stafford
}

April 2004

\begin{abstract}
Using a unique set of household level panel data, we estimate the effect of capital gains on saving by asset type, controlling for observable and unobservable household specific fixed effects. The results suggest that the decline in the personal saving rate since 1984 is largely due to the significant capital gains in corporate equities experienced over this period. Over five-year periods, the effect of capital gains in corporate equities on saving is substantially larger than the effect of capital gains in housing or other assets. Failure to differentiate wealth affects across asset types results in a significant understatement or overstatement of the size of their impact, depending on the asset.
\end{abstract}

JEL Classification: D12, E21

Keywords: Personal saving, wealth effect, capital gains

\footnotetext{
* University of Michigan, Board of Governors of the Federal Reserve System, RAND and University of Michigan, respectively. This research was supported by grants from the National Institute on Aging (NIA) to the University of Michigan and RAND and by a grant from the NIH to RAND. The opinions expressed are those of the authors and do not necessarily reflect the views of the Board of Governors of the Federal Reserve System or its staff.
} 


\section{Introduction}

According to national income accounts, personal saving in the United States was 1.7 percent of disposable income in 2001-its lowest level since 1934. This low follows a seventeen year fall from a value of 10.8 percent in 1984 . The decline is particularly striking as the saving rate averaged a relatively stable 7 to 10 percent from the end of World War II up to 1984. Despite the fall in personal saving, household balance sheets have actually improved over the past two decades owing largely to sizable capital gains, primarily in corporate equities.

In this paper, we estimate how much of the decline in the personal saving rate can be explained by the capital gains households received during the stock market boom of the 1980s and 1990s when real equity prices quadrupled. In contrast to previous studies, we use a unique set of household level panel data that provide measures of household saving and capital gains. Our results indicate that most of the decline in the personal saving rate over the 1990s can be explained by the unprecedented rise in the value of corporate equities. Moreover, we provide robust evidence that the spending response to capital gains in corporate equities is larger than capital gains in other assets, including housing. Although we estimate a total wealth effect of 3 cents to the dollar, a result roughly consistent with much of the literature, we show that this masks significant heterogeneity across asset type. In particular, our estimates suggest that a one-dollar capital gain in corporate equities increases spending by as much as 19 cents. $^{1}$

The rest of the paper is organized as follows. The next section describes the data source and the way we construct the main saving concepts of interest from this data. Section three summarizes the results obtained from our empirical models of the relationship between household saving and capital gains across several assets. The fourth section examines the extent to which our estimates of the wealth effects can account for the recent decline in personal saving. The final section provides our conclusions.

\section{Definitions of Wealth and Saving}

The measures of household saving and capital gains used in this paper are derived from the Panel Study of Income Dynamics (PSID). The PSID has gathered almost 30 years of extensive economic and demographic data on a nationally representative sample of approximately 5,000 (original) families and

\footnotetext{
${ }^{1}$ Past studies quantifying the wealth effect have yielded a range of results. Macroeconometric models of household consumption in the United States imply that an extra dollar of wealth increases spending by 2 to 5 cents. Relatively few studies have examined the wealth effect by asset type. Using aggregate data, Peek (1983) found a larger spending response to gains in net financial assets than to gains from owner-occupied housing. Peek's estimated response to capital gains in equities is large and in line with those reported in this paper. Other studies have used household level data to focus solely on the effect of housing wealth with varying results. While Hoynes and McFadden (1994) report a small positive spending response to housing gains, Englehardt (1995) reports a reduction in saving of roughly 14 cents per dollar of housing gain when the sample is restricted to non-movers. Skinner (1989) finds that, after controlling for fixed effects, capital gains in housing have little effect on saving. This is consistent with the results reported in this paper. See Poterba (2000) for an excellent survey of this literature.
} 
35,000 individuals living in those families. We use the PSID wealth modules included in the 1984, 1989, and 1994 surveys to examine the evolution of household wealth and saving over the ten-year period. These modules measure net equity in homes and non-housing assets divided into seven categories. The modules also include questions about new purchases and sales of individual assets so that, in principal, active and passive (capital gains) saving can be distinguished.

Total household wealth in the PSID is comprised of eight components: main home equity $\left(w_{1}\right)$, real estate other than home equity $\left(w_{2}\right)$, a farm or private business $\left(w_{3}\right)$, automobiles, motor homes, or boats $\left(w_{4}\right)$, checking and saving accounts, money market funds, certificates of deposit, government saving bonds, treasury bills including those in investment retirement accounts $\left(w_{5}\right)$, equities in publicly traded corporations, mutual funds, investment trusts, and investment retirement accounts $\left(w_{6}\right)$, other savings which include corporate bonds, rights in a trust or estate, the cash value of life insurance, and valuable collections $\left(w_{7}\right)$, and total non-collateralized debt, which is negative $\left(w_{8}\right)^{2}$

Total net wealth in each of the 1984, 1989 and 1994 waves of the PSID is simply $W_{t}=\sum_{k=1}^{8} w_{k t}$, where $t=1984$, 1989, or 1994. In 1989 and 1994, respondents were also asked about their active saving over the previous five years, defined as the net purchase of assets. These questions were specific to components of wealth where capital gains are most relevant including net investment in real estate other than the main home $\left(s_{2}\right)$, farm or business $\left(s_{3}\right)$, and corporate equities $\left(s_{6}\right){ }^{3}$ Active saving in housing $\left(s_{1}\right)$ is computed on an annual basis as it depends on the specific home ownership patterns of the family. ${ }^{4}$ For families living in the same house between two consecutive years, active saving over that year is the change in the mortgage principal and net investments in home improvement if they owned a home and zero otherwise. For households moving between two consecutive years, active saving is the change in home equity. ${ }^{5}$ Active saving in housing over a five-year period is the sum of active saving in each year. Finally, active saving in the remaining wealth components is the five-year difference in reported values.

Capital gains in real estate $\left(g_{2}\right)$, farm or business $\left(g_{3}\right)$, corporate equities $\left(g_{6}\right)$, and the main home $\left(g_{1}\right)$ are computed using the self-reported asset values and active saving. An asset can change in value for two reasons: either some of it is sold or purchased (active saving) or the price of the asset changes (capital gains/passive saving). As a result, the capital gain in an asset between any two points in time is, by definition, the change in its value less the active saving in that asset. Using the data in the

\footnotetext{
${ }^{2}$ All dollar values are converted to 1996 dollars using the chain price GDP deflator for personal consumption.

${ }^{3}$ Self-reported saving over the two fiver year periods are converted to 1996 dollars by using the five year average of the chain price GDP deflator for personal consumption.

${ }^{4}$ The PSID has questions on home ownership, house value, and the outstanding mortgage in each year of the survey.
} 
PSID, capital gains between 1984 and 1989 (and between 1989 and 1994) are defined as $g_{k t}=\Delta w_{k t}-s_{k t}$ for each asset, where $\Delta$ is a five-year difference operator.

The decomposition of changes in wealth into active saving and capital gains (passive saving) is complicated by transfers into the household's wealth portfolio that are not covered by the assets. These include inheritances and gifts from family and friends, as well as changes in family composition (e.g., a new spouse that owns a pre-existing automobile or checking account). For example, if a household receives an inheritance in the form of stocks, it may not get reported as active saving because an actual purchase was not made, and would incorrectly be treated as a capital gain. Since the form of an inheritance or gift is unknown, it is not possible to distinguish an inheritance of stocks from a capital gain in stocks. However, questions were asked in the 1989 and 1994 PSID wealth modules about the value of inheritances received and net transfers due to gifts from family or friends and changes in family composition. These values are used as controls in our modeling.

Wealth can also change owing to the liquidation of pensions. Because defined contribution pensions are not included in the PSID's measure of wealth, a household that liquidates a pension will incorrectly show an increase in wealth as the resources get channeled to the assets that are measured, albeit reduced by any amount consumed. As with inheritances, the value of assets removed from pension accounts was reported in the 1989 and 1994 survey. Our modeling of household saving below also measures this type of transfer.

Finally, defining these saving concepts with panel data requires a precise definition of the household. Households are defined as families in which the head of household did not change over the 1984 to 1994 period. Of the 6,915 households in the 1984 survey, there were 4,127 with the same head over the following ten years. This does not restrict the sample to households without changes in family composition (e.g. divorce). Because getting married or separated can have a large impact on the balance sheet if for no other reason than the combining (or dividing) of two people's assets, changes in marital status are taken into account in our analysis below.

Table 1 suggests a possible relationship between household active saving and capital gains in stocks by arraying these values across age and education groups. First, capital gains in stocks were larger, and active saving was lower, between 1989 and 1994 than between 1984 and 1989. Similarly, capital gains were concentrated among those 45 to 64 years old, in part because they had a longer time to accumulate stocks by 1984 and typically hold a larger share of equity in their portfolio relative to other

\footnotetext{
${ }^{5}$ Initial equity for those that moved from renting to owning is set to zero.
} 
age groups. ${ }^{6}$ But these are the same age groups that experienced the largest across period drop in active saving. With regard to education, by far the largest increase in capital gains was among college graduates who simultaneously reduced their active saving by 20 percent.

Because both older and higher educated households also have more income, the last two columns of Table 1 present mean saving rates across the two five year periods, defined as the ratio of mean active saving to mean total family income. While there was a slight increase in the saving rate among those households whose head was age 25 to 44, the saving rate of households aged 55 to 64 fell by four percentage points between the two periods. Similarly, the largest fall in the saving rate is observed among college-educated households where the rate dropped from 14.3 percent to 10.8 percent. Across both education and age, the largest decline in saving rates occurred where capital gains were the largest.

The PSID data covers a period of sizable capital gains in corporate equities. One implication of the wealth effect is that households who owned stocks at the beginning of the sample period should also be those with the largest reduction in saving. ${ }^{7}$ Table 2 reports the mean and median of household total active saving over the 1984 to 1989 and 1989 to 1994 periods, stratified by whether or not stocks were owned in 1984. Total active saving rates are shown in the last two columns. Not surprisingly, both the level and rate of total active saving is higher among stockholders. However, whether measured in levels or as a fraction of income, the decline in saving between the two five year periods is much larger among stockholders. For example, while the mean (median) saving rate of non-stockholders declined $0.1(0.4)$ percentage point, the mean (median) saving rate among stockholders declined 4.6 (3.5) percentage points. The concentration of the saving decline among those participating in the stock market in 1984 and therefore with exposure to capital gains over the entire ten-year period indicates that the stock market run up may have played a significant role.

\section{Empirical Model of Household Saving}

While the results in Tables 1 and 2 are suggestive of an effect of capital gains on active saving, multivariate modeling is necessary to isolate the relationship. The basic model we consider projects active saving onto capital gains, income and selected demographics. The variables of interest are observed twice for each household: once for the period 1984 to 1989 and once for the period 1989 to 1994. To be consistent with active saving and capital gains, income is measured twice as the sum of family income over each respective five-year period.

\footnotetext{
${ }^{6}$ Age groups are defined using the age of the head in 1984 for the 1984 to 1989 period and the age of the head in 1989 for the 1989 to 1994 period. Thus, saving comparisons can be made without the confounding age effect. ${ }^{7}$ Studies of the consumption based CAPM have noted that the consumption of stockholders is more highly correlated with stock returns than that of non-stockholders (Mankiw and Zeldes, 1991).
} 
Before reporting the results, two key statistical issues must first be addressed. First, considerable heterogeneity exists in saving behavior among what appear to be observationally equivalent households (Venti and Wise, 1999). Even among households with similar lifetime income paths, some are "savers" while others are not. Heterogeneity implies a strong positive association across households between saving and capital gains. Households who are active savers every year will have accumulated considerable wealth, thus increasing their exposure to the possibility of capital gains and losses. The panel aspect of the data is used to eliminate such household fixed effects by examining how withinhousehold changes in active saving respond to within-household changes in capital gains. Although fixed effects estimates eliminate the effect of demographic characteristics such as education, race and gender, we include demographic measures of age as well as indicators of transitions into and out of marriage.

A second issue stems from measurement error. ${ }^{8}$ Household wealth is measured with error and the same is certainly true for active saving. Measurement error has two effects on the estimated wealth effect for a given asset. The first is attenuation bias resulting from classical measurement error. More unique to the current estimation problem is a bias introduced by the method used to construct capital gains. For a given change in wealth, a positive error in active saving necessarily lowers measured capital gains by an equal amount. Thus, measurement error in active saving artificially induces a negative correlation with measured capital gains. In general, the two effects of measurement error operate in opposite directions and it is not possible to determine the direction of the overall bias. ${ }^{9}$

Eliminating the effect of attenuation bias is made difficult by a lack of valid instruments. However, we are able to mitigate the second source of bias, a more critical problem in our application as it unambiguously biases towards a larger negative effect. Our solution utilizes the availability of active saving and capital gains in multiple assets. The second bias stems from a definitional link between measured capital gains and active saving. To avoid the bias, we eliminate from total active saving the assets whose capital gains we are most interested in, namely publicly held corporate equities. Thus, we estimate the effect of capital gains on active saving in assets other than equities. Although the estimate is still biased by classical measurement error, this tends to produce a finding of no wealth effect. We show in the appendix that the estimated effect of capital gains in stocks on active saving in assets other than

\footnotetext{
${ }^{8}$ A perennial problem stems from the non-significant measurement error in household wealth (see Juster and Smith, 1997). To eliminate gross outliers from the sample, we trimmed the top and bottom distributions of each component of active saving and capital gains by excluding the top and bottom 50 cases. Our final sample consists of 3,008 households. The main result from our analysis, the magnitude of the impact of capital gains on active saving, is not sensitive to similar alternative trims. More is said regarding the robustness of our results below.

${ }^{9}$ In the appendix, the bias is decomposed into its two effects, and its impact on the estimated coefficients is examined.
} 
stocks avoids the definition-induced bias as long as the errors in measurement are independent across assets. $^{10}$

Table 3 reports the estimated effects of household capital gains on active saving. ${ }^{11}$ The results in the first column of Table 3 suggest active saving is quadratic in age. Marital transitions are captured by dummy variables indicating whether the household head married or whether the household head separated. ${ }^{12}$ Entry into marriage has little effect on saving relative to households who did not change marital status. In contrast, a divorce or separation indicates a significant decrease in saving, most likely reflecting the withdrawal of assets from the original family unit. Finally, the estimated marginal propensity to save out of income indicates that a dollar increase in income raises saving by roughly 8 cents.

We control for inheritances and net transfers into the household from gifts or loans and the liquidation of pensions so that such transfers do not contaminate the estimates of the wealth effect. Net transfers in the form of gifts, informal loans or pension liquidations do not appear to appreciably increase active saving, which may indicate that most of these resources are consumed. ${ }^{13}$ A dollar inheritance increases household wealth by 46 cents, but as mentioned above it is unclear how to interpret this effect since the form in which the inheritance was received is unknown.

Our primary interest centers on the impact of capital gains on active saving. As shown in column $i$ of Table 3, a dollar increase in total capital gains reduces saving by about 3 cents, consistent with many prior estimates of the wealth effect. However, this result substantially misstates the impact of capital gains on saving because the source of capital gains matters a great deal. In column $i i$, the effect of capital gains on saving is separated by asset type. A dollar of capital gains in stocks reduces active saving by

\footnotetext{
${ }^{10}$ By restricting the analysis to saving in assets other than stocks, a decrease in saving may simply reflect shifting resources toward stocks rather than a decline in overall saving. Table 2 reports separately active saving in assets other than stocks and active saving in stocks. Not surprisingly, some portfolio reallocation appears to have taken place. For example, among households that owned stocks in 1984, mean active saving in stocks increased by about $\$ 4,500$ between the 1984 to 1989 and 1989 to 1994 periods. However, mean active saving in other assets decreased by $\$ 21,700$ for these households, a far larger decline than the increase in saving in stocks. More generally, the correlation between the change in active saving in stock over the two five-year periods and the change in active saving in other assets is 0.029 and not statistically different from zero. Therefore, although households did reallocate their portfolio somewhat toward stocks, the magnitude is trivial relative to the overall decline in saving.

${ }^{11}$ In our interpretation of these results, we are implictly arguing that most of the capital gains over the past two decades was largely unexpected. This argument is supported both by the observation that the sheer magnitude of the gains was unlike any other period in the history of stock market and by recent work on the equity premium by Fama and French (2002), who suggest that higher than average returns in the post-World War II era produced higher than expected capital gains. Finally, dividends are captured through personal income, which we also controlled.

${ }_{12}$ The reference group - those that either stayed married or unmarried - represents 85 percent of the sample.

${ }^{13}$ It seems plausible that gifts and informal loans, as well as some pension liquidations, are intended for immediate consumption. However, it is unlikely that consumption should be affected by a pension roll-over into an IRA or Keogh account, suggesting that active saving should reflect the off-balance sheet infusion one-for-one.
} 
about nineteen cents. In contrast, the effect of capital gains in housing is smaller in magnitude and statistically insignificant, and the impact of capital gains in other tangible assets is essentially zero. ${ }^{14}$

The remaining columns in Table 3 present alternative tests of the robustness of our estimates. One possible explanation for the large capital gain effect from stocks may be due to the lack of PSID information on capital gains in pensions. Households with large capital gains in privately held stocks might have received large gains in their defined contribution pension plans, which were growing in popularity over the sample period. A positive correlation between capital gains in privately held equities and capital gains in pension equities would lead to an overstated estimate of the saving response to privately held equity gains alone. Although we are constrained by limited pension information in the PSID, column iii in Table 3 presents results from a model that includes the interaction between capital gains in the stocks and a dummy variable for the existence of a private pension for at least one spouse. Because those with a pension were likely to have larger total capital gains in stocks, the interaction term should be negative. Indeed, while the results suggest that the impact of capital gains in stocks is statistically significant for both those with and without pensions, the effect is more than twice as large for those respondents with a pension. The difference in the size of the capital gain effect between those with and without pensions does not necessarily suggest that these two types of households react differently to a given wealth increase. Rather, it may only indicate that the true size of the capital gain in corporate equities is larger for households with a pension.

Given the large effects that marital transitions can have on changes in household wealth, column $i v$ presents estimates restricting the sample to households who remained married in all three waves of the survey. The results show little difference from those based on the full sample indicating that marital transitions do not affect the estimated relationship between active saving and capital gains. Similarly, as highlighted in Table 1, there is a strong relationship between education and the portion of the decline in active saving that is attributed to capital gains. Although the estimated wealth effects in Table 3 control for all household fixed effects including education, column $v$ reports the estimated wealth effects when restricting the sample to households whose head has at least some college education. The results suggest a somewhat stronger effect of capital gains in equities and are consistent with the relationship seen in Table 1.

The results in columns $i$ through $i v$ contain the bias introduced by the one-for-one effect of measurement error in active saving on measured capital gains. As argued above, this bias can be

\footnotetext{
${ }^{14}$ Capital gains in the three components are roughly uncorrelated. As a result, the total wealth effect is approximately equal to the weighted average of the wealth effects of the three components. The weights reflect each capital gain component's share of the variance in total capital gains. The relative shares for housing gains, stock gains, and other gains are $0.21,0.22$ and 0.57 , respectively.
} 
mitigated by redefining active saving to exclude active saving in stocks. The results in columns $v i$ through $i x$ replicate those in columns $i$ through $i v$ using this redefined measure of active saving. Eliminating the bias reduces the magnitude of the wealth effect, as hypothesized, but by a trivial amount. The estimated effect of capital gains in corporate equities are reduced from -0.191 in column $i i$ to -0.183 in column vi. This may not be surprising since active saving in stocks is a small part of total active saving. After eliminating the impact of saving heterogeneity and the definition induced measurement error, only classical measurement error remains. This tends to bias the results toward finding no effect of stock market gains.

To further examine the robustness of the results in Table 3, we considered two alternative methods of estimation. The first method applies the median regression estimator to models $i i$ and $v i$ in Table 3. The second method estimates models $i i$ and $v i$ by first dropping observations that contain a high degree of leverage and yield a large residual, and then re-weighting the remaining data with weights that are inversely related to the sample residuals. ${ }^{15}$ The effect of capital gains on active saving is reduced somewhat to -0.154 when estimated by median regression and to -0.121 when estimated by the reweighted regression. When saving in stocks is removed from active saving, the effect of capital gains in stocks is -0.148 and -0.161 when estimated by the median and re-weighted regressions, respectively. All results remain highly significant suggesting that our estimates in Table 3 are quite robust. ${ }^{16}$

\section{Discussion}

\section{A. Accounting for the Decline in Personal Saving: 1984 to 1999}

Can the estimated effects of capital gains account for the decline in the rate of personal saving in the United States over the past two decades? To answer this question, we apply the results from the models in Table 3 to aggregate data. We confine the analysis to movements in income and capital gains in corporate equities and owner-occupied housing. Aggregate personal income data comes from the National Income and Product Accounts and aggregate household capital gains data comes from the Federal Reserve's Flow of Funds. ${ }^{17}$

Predicted personal saving is computed at an annual frequency by applying the estimated coefficients from Table 3 to aggregate real personal income and capital gains. This is then divided by aggregate disposable personal income to obtain the predicted personal saving rate. Because the estimated

\footnotetext{
${ }^{15}$ The criterion for the first stage of the estimation is to drop observations with a Cook's D-statistic larger than 1.0 (Cook, 1979). Only one observation was dropped. In the second stage, weights are determined iteratively based on within-sample absolute errors as recommended by Huber (1964).

${ }_{17}^{16}$ Results are available from the authors upon request.

${ }^{17}$ Nominal values are converted to 1996 dollars using the GDP personal consumption deflator.
} 
wealth effects are based on saving over five-year increments beginning in 1984, we consider the average saving rate over the periods 1984 to 1989,1989 to 1994 and 1994 to 1999.

Table 4 presents the results of this exercise. The first column reports the average NIPA personal saving rate, while the second column displays the predicted average saving rate based on the estimated effect of total capital gains reported in column $i$ of Table 3. The third column shows the predicted average saving rate based on the estimated effects of capital gains separated by asset type, as reported in column $i$ of Table 3 . Across the full ten-year period, the estimated total wealth effect suggests only a 0.7 percentage point decline in the average saving rate over the three periods. In contrast, allowing for separate wealth effects by asset type implies a decline of 4.4 percentage points. The actual decline in the average personal saving rate was 4.5 percentage points.

\section{B. Why should wealth effects vary by asset type?}

Spending may differ across assets for several reasons. First, transaction costs related to borrowing against housing equity could imply a lower marginal propensity to consume out of capital gains in housing relative to capital gains in equity, all else being equal. Second, the marginal propensity to consume may differ across assets because of varying perceptions of liquidity. That is, liquidity constraints can be self-imposed for behavioral reasons (Shefrin and Thaler, 1988). Households may not treat money that is stored in different places as perfect substitutes. Rather, they may divide their wealth into different "mental accounts," each with its own marginal propensity to consume owing to varying degrees of self-imposed liquidity. This argument could suggest that a dollar capital gain is considered more discretionary than a dollar of existing wealth. This may be particularly true for gains in stocks that are largely unanticipated and viewed as windfalls.

Third, and perhaps most important, some assets serve more than one purpose. This is particularly true for housing because homeowners are on both sides of the housing market. To many homeowners, house price increases may be seen as a mixed blessing. Younger households who own their own homes may see rising house prices as a problem if they desire to upgrade their homes in the future as their families grow. As a result, although housing is an instrument for savings, its additional role of a consumption good likely dampens the spending response to price appreciation. ${ }^{18}$

\footnotetext{
${ }^{18}$ The magnitude of the effect of housing gains may seem small in light of the rising popularity of home equity loans. However, the growing use of home equity financing represents more of a structural shift in the financing market than a reaction to rising house values. For example, the value of home mortgages in the PSID increased as much in the 1989 to 1994 period as during the 1984 to 1989 period even though the value of homes were falling between 1989 and 1994 and rising between 1984 and 1989. Parker (1999) also concludes that financial innovation was unlikely to have caused the recent consumption boom.
} 


\section{How plausible are the estimated wealth effects?}

Some have argued that if the planning horizon is the expected end of life, consumption from a gain in wealth should be allocated over the remaining years, implying a small saving effect from capital gains. In a simple benchmark model of consumption, the marginal propensity to consume should be on the order of 0.06, a value consistent with the macroeconometric literature (Poterba, 2000). But going back to the pioneering work of Milton Friedman, there is a large body of research suggesting that planning horizons are much shorter (Friedman, 1957). Retirement is not the only motive for saving. For motives such as saving for college expenses for children, horizons are much shorter so that impact of capital gains on saving may be larger. In addition, uncertainty and impatience, combined with liquidity constraints, generates buffer-stock saving behavior, which implies that households consume a much larger fraction of a wealth gain than the simple benchmark model suggests. Indeed, the estimated wealth effect from stocks, reported in Table 3, is on the lower bound of those simulated in Carroll (1997).

Our results are most closely aligned with those of Parker (1999), who also uses the PSID wealth data to examine the decline in the personal saving rate. Although Parker concludes that the increase in household wealth explains little of the decline in personal saving, this is based on an estimated total wealth effect that is entirely consistent with our results using total capital gains from column $i$ of Table 3 . As indicated in Table 4, very little of the decline in the personal saving rate can be explained by capital gains when applying a single total wealth effect to aggregate data. It is only when wealth effects are differentiated by asset type that capital gains are enough to explain the saving decline. ${ }^{19}$ The implication of our analysis for explaining the drop in personal saving and that of Parker's is quite different.

Another explanation for the size of our results relative to previous studies relates to the periodicity of PSID wealth modules. We are estimating the effect of capital gains over five years. While this restriction was survey induced, it may inadvertently bring an analytical advantage. Given the extreme variability in stock prices, consumption smoothing households may not want to vary their consumption to react to daily, monthly, or even yearly equity price movements. Significant short-run price variability could signal uncertainty regarding an asset's value and households may react with understandable caution in adjusting their consumption to any change in prices. Some changes in

\footnotetext{
${ }^{19}$ Parker finds that the change in consumption is similar for people at different levels of wealth, which he concludes is inconsistent with a wealth effect. However, this result is based on a comparison across total wealth. The results in this paper are based on a comparison across capital gains in corporate equity. There is very little relation between cross-sectional wealth levels and capital gains in corporate equity in the PSID. For example, even after trimming the data to conform to the data used in section III, the simple correlation between total household wealth and total stock wealth in the 1984 PSID is only 0.4. More relevant, the correlation between 1984 wealth (essentially the variable Parker uses) and subsequent capital gains in stocks from 1984 to 1994 (our measure) is only 0.07 . Eliminating the potential definition induced bias, the correlation between 1984 wealth and capital gains in stocks from 1989 to 1994 is 0.16 .
} 
consumption such as durable goods may have to meet threshold requirements before changes take place (Grossman and Laroque, 1990). Similarly, consumption habit formation implies a larger long run than short-run responses to wealth changes as households are more inclined to slowly adjust their consumption (Carroll, 1997). Whatever the reason, if individuals slowly adjust their consumption, the initial response to a capital gain may be smaller than the five-year effect we are estimating.

\section{Conclusion}

This paper has reached several conclusions. Most important, our results suggest that the decline in the personal saving rate since 1984 is largely due to the significant capital gains in corporate equities experienced over this period. Over five-year periods, the effect of capital gains in corporate equities on saving is substantially larger than the effect of capital gains in housing or other assets. Failure to differentiate wealth affects across asset types results in a significant understatement or overstatement of the size of their impact, depending on the asset.

Additional tests of the impact of capital gains on saving would be desirable, particularly those that differentiate by asset type. One fruitful avenue to pursue may be cross-national differences. Countries differ significantly in the extent to which households participate in the corporate equity market as well as in the magnitude of local stock market fluctuations over time. Because countries also vary considerably in secular trends in national saving rates, the correspondence between country specific saving rates and stock market indexes may provide a powerful test of the wealth effect. In addition, a better reconciliation of recent trends in household saving and consumption would help increase our confidence in the appropriate role that should be assigned to wealth effects in explaining household behavior. 


\section{Appendix: Empirical Model with Fixed Effects and Measurement Error}

Measurement error biases the OLS estimation of the effect of capital gains on saving in two ways. The first is attenuation bias and the second stems from the manner in which capital gains are defined. Assume that a single asset is measured over three periods. In the second and third period, we obtain active saving information over the previous period in each asset. Our model is:

$$
s_{i t}^{*}=\beta_{1} g_{i t}^{*}+\beta x_{i t}+\alpha_{i}+\eta_{i t}
$$

where $s_{i t}^{*}$ is active saving, $g_{i t}^{*}$ is capital gains and $x_{i t}$ is a vector of variables including such things as a constant, income and other demographics. Saving, capital gains, and income are measured over the periods $t-1$ to $t$.

Although we assume $\eta_{i t}$ is independently and identically distributed, the household specific fixed effect, $\alpha_{i}$, may be correlated with $g_{i t}^{*}$ and $x_{i t}$.

For each household, we directly observe active saving and wealth as ( $i$ suppressed):

$$
\begin{array}{ll}
s_{t}=s_{t}^{*}+\varepsilon_{t} & t=1,2 \\
w_{t}=w_{t}^{*}+\mu_{t} & t=0,1,2
\end{array}
$$

where $s_{t}^{*}$ and $w_{t}^{*}$ are the true values of active saving and wealth, and $\varepsilon_{t}$ and $\mu_{t}$ are independent measurement errors with variances $\sigma_{\varepsilon}^{2}$ and $\sigma_{\mu}^{2} \cdot{ }^{20}$ By definition, capital gains are given as:

$$
g_{t}=w_{t}-w_{t-1}-s_{t}=\mathrm{g}_{t}^{*}+\left(\mu_{t}-\mu_{t-1}-\varepsilon_{t}\right), \quad t=1,2
$$

where $g_{t}^{*}=w_{t}^{*}-w_{t-1}^{*}-s_{t}^{*}$. Note that measurement error in active saving and capital gains share a common component, $\varepsilon_{t}$.

To control for the household fixed effect, which may be correlated with capital gains, the wealth effect is estimated using the the relationship between how the saving of each household responds to the change in their own capital gains. Changes in active saving and capital gains are given as:

$$
\begin{aligned}
& \Delta s=s_{2}^{*}-s_{1}^{*}+\varepsilon_{2}-\varepsilon_{1} \\
& \Delta g=\left(w_{2}^{*}-2 w_{1}^{*}+w_{0}^{*}\right)-\left(s_{2}^{*}-s_{1}^{*}\right)+\left(\mu_{2}-2 \mu_{1}+\mu_{0}-\varepsilon_{2}-\varepsilon_{1}\right) .
\end{aligned}
$$

Consider the following regression of saving on capital gains (demeaned), suppressing variation in $\mathrm{X}$ for expositional purposes:

Estimation of $\beta$ by OLS yields,

$$
\Delta s_{i}=\beta \Delta g_{i}+u_{i} .
$$

$$
\hat{\beta}_{\text {ols }}=\operatorname{Cov}(\Delta s, \Delta g) \operatorname{Var}(\Delta g)^{-1} .
$$

The relationship between $\hat{\beta}_{\text {ols }}$ and the OLS estimate without measurement error, $\hat{\beta}_{\text {ols }}^{*}$, is given by

$$
\hat{\beta}_{o l s}=\hat{\beta}_{o l s}^{*}\left(\frac{\operatorname{Var}\left(\Delta g^{*}\right)}{6 \sigma_{\mu}^{2}+2 \sigma_{\varepsilon}^{2}+\operatorname{Var}\left(\Delta g^{*}\right)}\right)-\left(\frac{2 \sigma_{\varepsilon}^{2}}{6 \sigma_{\mu}^{2}+2 \sigma_{\varepsilon}^{2}+\operatorname{Var}\left(\Delta g^{*}\right)}\right) .
$$

The relationship indicates that are two effects of measurement error. The first term in parentheses is attenuation bias resulting from classical measurement error. More unique to the current estimation problem is the second term. Because this term is positive, the effect biases $\hat{\beta}_{\text {ols }}$ downward, making it more negative. This bias is a result of measurement error in active saving and the definition of capital gains: note that the numerator of the second term is $\sigma_{\varepsilon}$ rather than the variance of $g^{*}$.

The solution proposed in this paper is to eliminate the measurement error component of the covariance between active saving and capital gains by eliminating from active saving the assets whose capital gains we are interested in, namely corporate equities. Consider a model with two assets, $w_{1 t}$ and $w_{2 t}$, as well the saving in each of these assets, $s_{1 t}$ and $s_{2 t}$. As above, we observe the saving and value of the two assets with error:

\footnotetext{
${ }^{20}$ Allowing the variances of the measurement errors to change over time or display serial dependence does not affect the main result.
} 


$$
\begin{aligned}
& s_{k t}=s_{k t}^{*}+\varepsilon_{k t} \quad k=1,2 \quad t=1,2 \\
& w_{k t}=w_{k t}^{*}+\mu_{k t} \quad k=1,2 \quad t=0,1,2 .
\end{aligned}
$$

We assume that measurement errors are independent across assets. Capital gains for each asset are defined as:

$$
\begin{aligned}
s_{k t} & =w_{k t}-w_{k t-1}-s_{i t} \\
& =g_{k t}^{*}+\left(\mu_{k t}-\mu_{k t-1}-\varepsilon_{k t}\right) \quad k=1,2 \quad t=1,2
\end{aligned}
$$

where $g_{k t}^{*}=w_{k t}^{*}-w_{k t-1}^{*}-s_{k t}^{*}$. Now consider the effect of capital gains in asset 2 on saving in asset $1, \lambda$. As above, the model is estimated in first differences to eliminate household specific fixed effects. In regressing $\Delta s_{1}$ on $\Delta g_{2}$, the covariance between the two variables reduces to $\operatorname{Cov}\left(\Delta s_{1}^{*}, \Delta g_{2}^{*}\right)$ and the estimate of the effect of $\Delta g_{2}$ on $\Delta s_{1}$ is given by

$$
\hat{\lambda}_{\text {ols }}=\hat{\lambda}_{\text {ols }}^{*}\left(\frac{\operatorname{Var}\left(\Delta g_{2}^{*}\right)}{6 \sigma_{\mu_{2}}^{2}+2 \sigma_{\varepsilon_{1}}^{2}+\operatorname{Var}\left(\Delta g_{2}^{*}\right)}\right) .
$$

The definition induced bias no longer exists and we are only left with attenuation bias. 


\section{References}

Bernheim, D. B., J. Skinner, and S. Weinberg, "What Accounts for the Variation in Retirement Wealth Among U.S. Households?" American Economic Review 91:4 (2001), 832-857.

Carroll, C. D., "Buffer-Stock Saving and the Permanent Income Hypothesis," Quarterly Journal of Economics 112:1 (1997), 1-56.

Cook, R. D., "Influential Observations in Linear Regressions," Journal of the American Statistical Association 74:365 (1979), 169-174.

Deaton, A. S., "Saving and Liquidity Constraints," Econometrica 59:5 (1991), 1221-1248.

Engelhardt, G. V., "House Prices and Home Owner Saving Behavior," NBER working paper no. 5183 (1995).

Fama, Eugene and Kenneth French “The Equity Premium,” The Journal of Finance, 2002, 58:2, pp. 637659)

Friedman, M., A Theory of the Consumption Function (Princeton: Princeton University Press, 1957).

Grossman, Sanford J., and Guy Laroque, "Asset Pricing and Optimal Portfolio Choice in the Presence of Illiquid Durable Consumption Goods," Econometrica, 58: (1990), 25-51.

Hoynes, H., and D. McFadden, "The Impact of Demographics on Housing and Non-Housing Wealth in the United States," NBER working paper no. 4666 (1994).

Huber, P. J., "Robust Estimation of a Location of Parameter," Annals of Mathematical Statistics 35 (1964), 75-101.

Koenker, R., and G. Bassett, Jr., "Regression Quantiles,” Econometrica, 46:1 (1978), 33-50.

Juster, T. F., and J. P. Smith, "Improving the Quality of Economic Data: Lessons from HRS and AHEAD," Journal of the American Statistical Association 92:440 (1997), 1268-1278.

Lupton, J. P., and J. P. Smith, "Marriage, Assets and Savings," in Shoshana Grossbard-Shechtman (Ed.), Marriage and the Economy: Theory and Evidence from Advanced Industrial Societies (New York and Cambridge: Cambridge University Press, 2001).

Mankiw, N. Gregory and Stephen P. Zeldes, "The Consumption of Stockholders and Nonstockholders," Journal of Financial Economics, 29: (1991), 97-112.

Parker, J. A., "Spendthrift in America: On Two Decades of Decline in the U.S. Personal Saving Rate," University of Wisconsin Working Paper (1999).

Peek, J., "Capital Gains and Saving Behavior," Journal of Money, Credit and Banking 15:1 (1983), 1-23.

Poterba, J. M., "Stock Market Wealth and Consumption," Journal of Economic Perspectives 14:2 (2000), 99-118.

Shefrin, Hersh M. and Richard Thaler, "The Behavioral Life-Cycle Hypothesis," Economic Inquiry, 26:4 (1988), 169-177.

Skinner, J., "Housing Wealth and Aggregate Saving," Regional Science and Urban Economics 19:2 (1989), 213-216.

Venti, S. F., and D. A. Wise, "Lifetime Income, Saving Choices and Wealth at Retirement," in J. P. Smith and R. Willis (Eds.), Wealth, Work and Health: Innovations in the Social Sciences (Ann Arbor, MI: University of Michigan Press, 1999). 
Table 1. - Active Saving and Capital Gains in Stocks

\begin{tabular}{|c|c|c|c|c|c|c|}
\hline & \multicolumn{2}{|c|}{1984 to 1989} & \multicolumn{2}{|c|}{1989 to 1994} & \multicolumn{2}{|c|}{ Saving Rate } \\
\hline & $\begin{array}{l}\text { Active } \\
\text { Saving }\end{array}$ & $\begin{array}{c}\text { Capital Gains } \\
\text { in Stocks }\end{array}$ & $\begin{array}{l}\text { Active } \\
\text { Saving }\end{array}$ & $\begin{array}{l}\text { Capital Gains } \\
\text { in Stocks }\end{array}$ & $\begin{array}{c}1984 \text { to } \\
1989\end{array}$ & $\begin{array}{c}1989 \text { to } \\
1994\end{array}$ \\
\hline Full Sample & 24.6 & 1.7 & 20.2 & 9.4 & 9.9 & 8.0 \\
\hline \multicolumn{7}{|l|}{ Age of head } \\
\hline $25-44$ & 27.5 & 1.8 & 30.0 & 7.3 & 9.8 & 10.1 \\
\hline $45-54$ & 39.8 & 5.5 & 27.6 & 14.0 & 12.8 & 9.1 \\
\hline $55-64$ & 23.9 & -3.0 & 15.4 & 17.9 & 10.3 & 6.3 \\
\hline 65 or older & 1.5 & 3.5 & -2.8 & 3.4 & 1.1 & -2.2 \\
\hline \multicolumn{7}{|l|}{ Education of head } \\
\hline no h.s. degree & 9.1 & -1.0 & 7.9 & 3.8 & 5.9 & 5.5 \\
\hline h.s. degree or some college & 19.9 & 0.9 & 15.7 & 6.9 & 8.3 & 6.6 \\
\hline college degree or more & 54.8 & 6.7 & 44.3 & 21.1 & 14.3 & 10.8 \\
\hline
\end{tabular}

Sample consists of PSID households whose head was in 1984, 1989 and 1994. The top and bottom 1\% of total active and passive saving were dropped (3,969 observations). 1984 sample weights used in all calculations. Active saving is comprised of self reported savings in individual assets. Passive saving is defined as the difference between the change in value of assets over a given five year periods and the active saving in that asset. Saving rate is defined as the ratio of mean total active saving over the five year period to the sum of total family income over that same period. Age of head defined as of 1984 for the 1984 to 1989 period and as of 1989 for the 1989 to 1994 periods. Dollar values are in thousands of 1996 dollars.

Table 2. - Saving by Stock Ownership

\begin{tabular}{|c|c|c|c|c|c|c|c|c|}
\hline & \multicolumn{6}{|c|}{ Saving } & \multirow{2}{*}{\multicolumn{2}{|c|}{ Saving Rate }} \\
\hline & \multicolumn{2}{|c|}{ Total } & \multicolumn{2}{|c|}{ Stocks } & \multicolumn{2}{|c|}{ Total less Stocks } & & \\
\hline & $\begin{array}{c}1984- \\
1989\end{array}$ & $\begin{array}{c}1989- \\
1994\end{array}$ & $\begin{array}{c}1984- \\
1989\end{array}$ & $\begin{array}{c}1989- \\
1994\end{array}$ & $\begin{array}{c}1984- \\
1989\end{array}$ & $\begin{array}{c}1989- \\
1994\end{array}$ & $\begin{array}{c}1984- \\
1989\end{array}$ & $\begin{array}{r}1989 \\
1994 \\
\end{array}$ \\
\hline \multicolumn{9}{|l|}{ Full Sample } \\
\hline Mean & 24.6 & 20.2 & 3.1 & 6.1 & 21.5 & 14.1 & 9.9 & 8.0 \\
\hline Median & 7.6 & 5.4 & 0.0 & 0.0 & 6.9 & 3.8 & 3.6 & 2.7 \\
\hline \multicolumn{9}{|c|}{ Do Not Own Stock in 1984} \\
\hline Mean & 15.7 & 16.2 & 0.9 & 3.3 & 14.8 & 12.9 & 7.7 & 7.6 \\
\hline Median & 4.6 & 3.7 & 0.0 & 0.0 & 4.2 & 2.8 & 2.5 & 2.1 \\
\hline \multicolumn{9}{|c|}{ Own Stock in 1984} \\
\hline Mean & 47.7 & 30.5 & 8.8 & 13.3 & 38.9 & 17.2 & 13.2 & 8.6 \\
\hline Median & 24.3 & 13.2 & 0.0 & 0.0 & 21.7 & 8.2 & 7.8 & 4.3 \\
\hline
\end{tabular}

Sample consists of PSID households whose head was in 1984, 1989 and 1994. The top and bottom 1\% of total active and passive saving were dropped (3,969 observations). 1984 sample weights used in all calculations. Saving rate is defined as the ratio of mean (median) total active saving over the five year period to the mean (median) of the sum of total family income over that same period. The mean age difference between households owning stocks and households not owing stocks is 1.5 years in 1984. Dollar values are in thousands of 1996 dollars. 
Table 3. - Effects of Capital Gains on Active Saving

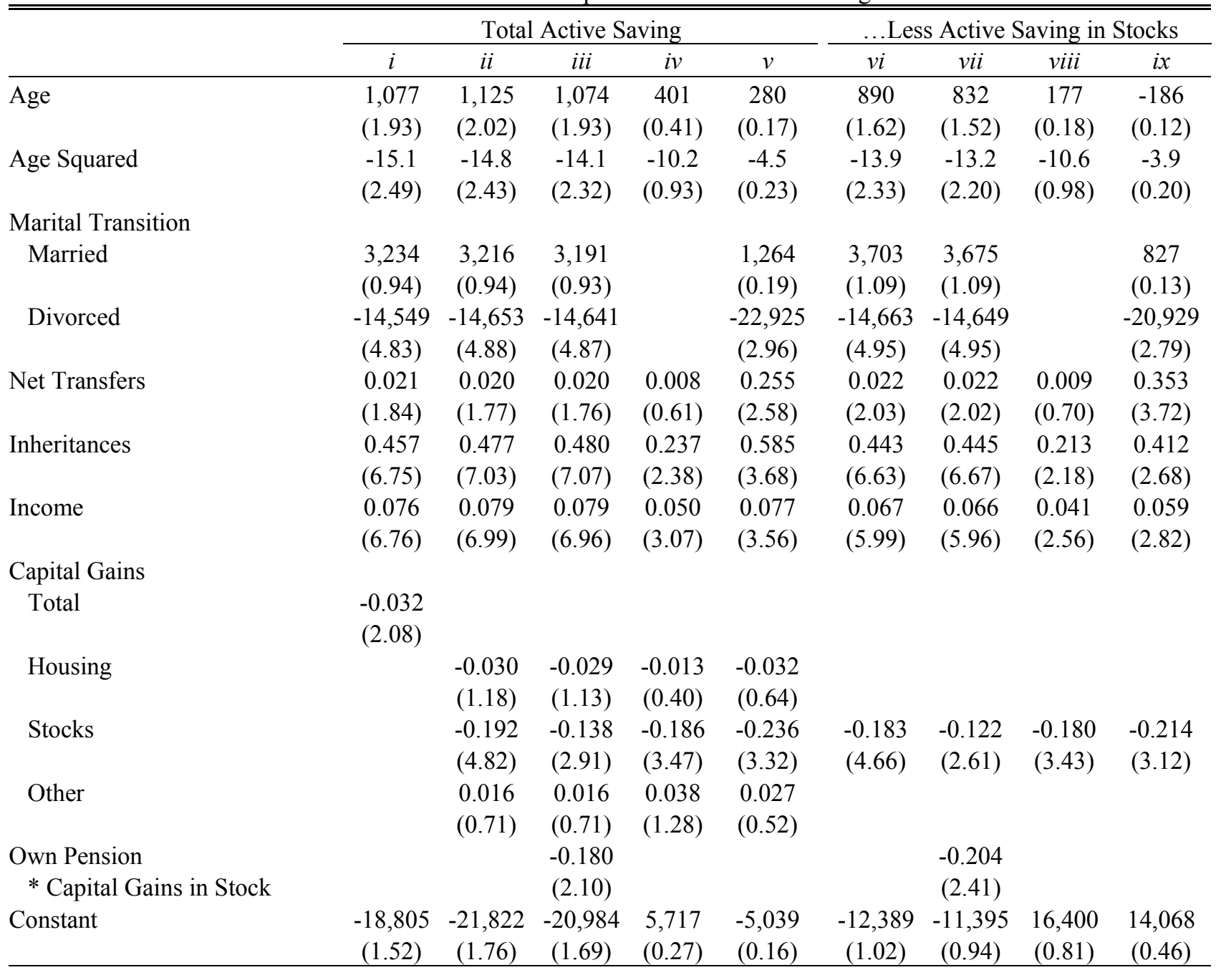

Models $i$ through $i i i$ and $v i$ and vii are estimated using the full sample, models $i v$ and viii are estimated using married households only and models $v$ and $i x$ are estimated using households whose head has at least some college education. Sample consists of PSID households whose head was in 1984, 1989 and 1994. Observations were dropped if they fell within the top or bottom 50 values of any active saving or capital gain component (3,008 observations). Net transfers include assets and debts brought into the households by new family members, and the liquidation of pension accounts. Age of head are defined as of 1984 for the 1984 to 1989 periods and as of 1989 for the 1989 to 1994 period. Models are estimated using the fixed effects estimator; t-statistics are in parentheses. 
Table 4. - Model Prediction of Average Personal Saving Rate

\begin{tabular}{cccc}
\hline \hline & \multirow{2}{*}{ NIPA Saving Rate } & \multicolumn{2}{c}{ Predicted Saving Rate } \\
\cline { 3 - 4 } & & Total & Separate \\
\hline 1984 to 1988 & 8.5 & 8.6 & 7.1 \\
1989 to 1994 & 7.0 & 8.5 & 6.5 \\
1994 to 1999 & 4.0 & 7.9 & 2.7 \\
\hline
\end{tabular}

The NIPA saving rate is reported as the average annual saving rate over the respective period in each row. The predicted saving rate is computed at an annual frequency using the estimated model coefficients from models $i$ and $i i$ in Table 3 combined with NIPA data on disposable personal income and the Federal Reserve's Flow of Funds data on capital gains. Only the effect from income and capital gains in housing and corporate equities are considered. The predicted annual saving rates are then averaged over the respective period in each row. Columns $i$ and $i i$ correspond to the resulting values using the coefficients from models $i$ and $i i$ in Table 3, respectively. 